\title{
ENTREPRENEUR
}

Jurnal Bisnis Manajemen Dan Kewirausahaan

Program Studi Manajemen Fakultas Ekonomika dan Bisnis Universitas Majalengka

Published every January and July e-ISSN : (Proses), p-ISSN: 2723-1941

Available online https://ejournal.unma.ac.id/index.php/entrepreneur

\section{Pengaruh Work Family Conflict Terhadap Komitmen Organisasi}

\section{Nita Hernita}

Fakultas Ekonomika dan Bisnis Universitas Majalengka

Email : hernita.eldibba@unma.ac.id

\begin{abstract}
Human resources are an important component in a company. The progress of the company can be seen from the involvement of human resources in it. The purpose of this study is to determine the effect of Work Family Conflict on organizational commitment. The research method uses a descriptive verification approach with quantitative data types. The study population was employees of PT. Shoetown Majalengka, totaling 323 employees. The sample was determined using random sampling techniques with a sample size of 100 employees, with a Likert scale of measurement (1-5). Data analysis was performed through correlation analysis, and t-test with processing using the SPSS Version 21 application. The results showed that Work Family Conflict had a negative and significant effect on organizational commitment.
\end{abstract}

\section{Keywords:}

Work Family Conflict; Organizational Commitment 


\section{ENTREPRENEUR}

\section{Jurnal Bisnis Manajemen Dan Kewirausahaan}

Program Studi Manajemen Fakultas Ekonomika dan Bisnis Universitas Majalengka

Published every January and July e-ISSN : (Proses), p-ISSN: 2723-1941

Available online https://ejournal.unma.ac.id/index.php/entrepreneur

\section{PENDAHULUAN}

Perkembangan suatu organisasi tidak lepas dari pentingnya peran Sumber daya manusia serta komponen lainnya. Organisasi dapat dikatakan baik ketika memiliki keseimbangan dalam pembagian tugas setiap bagian didalamnya. Sumber daya manusia didalam sebuah perusahaan mampu membangun visi perusahaan. Perusahaan akan berusaha mempertahankan karyawan ketika karyawan tersebut memiliki sebuah komitmen dan dedikasi yang penuh terhadap perusahaan tempatnya bekerja. PT.Shoetown Kabupaten Majalengka yang memiliki karyawan 323 dengan $78 \%$ karyawan nya merupakan karyawan wanita dengan kecenderungan memiliki tugas lain selain sebagai pekerja juga sebagai ibu dan istri dirumahnya. Terbangunnya komitmen organisasi yang baik tidak terlepas dari kemampuan seorang pegawai untuk menyeimbangkan antara perannya sebagai pekerja dan di dalam keluarga. Keseimbangan ini penting diwujudkan, karena berdampak negative pada komitmen organisasi. (Legowo et al., 2019) menyatakan bahwa Work Family Conflict memiliki pengaruh yang negatif signifikan terhadap komitmen organisasi. Artinya bahwa semakin tinggi work family conflict yang dialami oleh pegawai, maka akan semakin rendah komitmen organisasi dalam diri seorang pegawai.

\section{KERANGKA PEMIKIRAN DAN HIPOTESIS \\ Work to family conflict}

Work to family conflict memiliki tiga bentuk (Amelia, 2010) diantaranya :

1. Konflik karena waktu (time based conflict)

Time based conflict terbagi ke dalam dua bentuk, yaitu (1) tekanan waktu yang terhubungan dengan keanggotaan salah satu peran, yang menjadikan seseorang tidak memungkinkan untuk memenuhi harapan pada peran yang lainnya, (2) Kenyamanan yang muncul saat menjalani salah satu peran, walaupun secara fisik seseorang tersebut sedang menjalankan tuntutan peran yang lain. Pekerjaan merupakan sumber konflik (work related sources of conflict)) diantaranya; jumlah jam kerja, waktu lembur, absensi, ketidakaturan shift dan pengendalian jadwal kerja. Keluarga merupakan sumber konflik (family related sources of conflict) yakni terdapat tuntutan peran terhadap keluarga dalam menghabiskan waktu bersama keluarga. Wanita yang menggunakan waktu untuk bekerja diluar rumah tentunya akan memiliki kecenderungan mengalami tekanan peran dari aktivitas yang dijalaninya.(Robbin \& Judge, 2015). Bentuk komitmen organisasi berdasarkan Mayer dan Allen dalam (Kaswan, 2012) menerangkan bahwa komitmen organisasi mempunyai tiga dimensi yaitu :

1. Komitmen Afektif

2. Komitmen Kelanjutan

3. Komitmen Normatif

\section{Hubungan Work family Conflict dengan Komitmen Organisasi}

(Saraswati et al., 2014) mengemukakan bahwa individu yang mengalami konflik peran akan dengan mudah mengalami rasa cemas, ketidakpuasan dan ketidakefektifan untuk melaksanakan pekerjaan jika dibandingkan dengan individu lainnya. Selaras dengan hasil penelitian yang dilakukan oleh (Anisykurlillah $\square$ et al., 2013) bahwa terdapat korelasi negatif antara konflik peran terhadap komitmen organisasi. Maka disimpulkan bahwa konflik peran berpengaruh negative terhadap komitmen organisasi. 


\section{ENTREPRENEUR}

Jurnal Bisnis Manajemen Dan Kewirausahaan

Program Studi Manajemen Fakultas Ekonomika dan Bisnis Universitas Majalengka Published every January and July e-ISSN : (Proses), p-ISSN: 2723-1941 Available online https://ejournal.unma.ac.id/index.php/entrepreneur

\begin{tabular}{|c|c|}
\hline $\begin{array}{l}\text { Work family } \\
\text { Conflict }\end{array}$ & $\mathrm{H} 1 \begin{array}{l}\text { Komitmen } \\
\text { Organisasi }\end{array}$ \\
\cline { 2 - 3 }
\end{tabular}

Gambar 1 Kerangka pemikiran

\section{Hipotesis}

H1 : Terdapat pengaruh antara Ambiguitas Peran dengan Komitmen Organisasi

\section{METODE PENELITIAN}

Metode penelitian melalui pendekatan deskriptif verifikatif dan jenis penelitian survey dengan menggunakan sampel yang dijadikan sebagai data penelitian. Kabupaten Majalengka yang berjumlah 323. Jumlah sample 100 karyawan. Data diperoleh melalui kuesioner dengan pengukuran menggunakan skala likert (1-50). Analisis data dengan menggunakan analisis korelasi, varibelnya

\section{Tabel 1. Operasionalisasi Variabel}

\begin{tabular}{|c|c|c|}
\hline Variable & Definisi Operasional & Indikator - indikator \\
\hline $\begin{array}{l}\text { Work Family } \\
\text { Conflict }(\mathrm{X})\end{array}$ & $\begin{array}{l}\text { Keadaan karyawan ketika } \\
\text { mengalami dua atau lebih } \\
\text { tuntutan dalam waktu yang } \\
\text { bersamaan sehingga } \\
\text { kesulitan untuk memenuhi } \\
\text { tuntutan tersebut }\end{array}$ & $\begin{array}{l}\text { 1. Menyelesaikan pekerjaan dengan cara berbeda dan } \\
\text { menerima penugasan tanpa sumber daya yang } \\
\text { cukup untuk menyelesaikannya } \\
\text { 2. Mengesampingkan aturan dalam menyelesaikan } \\
\text { pekerjaan dan menerima permintaan dari kedua } \\
\text { pihak atau lebih yang tidak sesuai antara satu } \\
\text { dengan yang lainnya } \\
\text { 3. Melakukan pekerjaan yang cenderung diterima satu } \\
\text { pihak saja dan seringkali melakukan pekerjaan } \\
\text { yang tidak perlu } \\
\text { 4. Bekerja dibawah arahan dan perintah tidak jelas }\end{array}$ \\
\hline $\begin{array}{l}\text { Komitmen } \\
\text { Organisasi (Y) }\end{array}$ & $\begin{array}{l}\text { Keadaan dimana karyawan } \\
\text { percaya dan menerima } \\
\text { tujuan organisasi serta } \\
\text { berniat tidak akan } \\
\text { meninggalkan } \\
\text { organisasinya }\end{array}$ & $\begin{array}{ll}\text { a. Kemauan karyawan } \\
\text { b. Kesetiaan karyawan } \\
\text { c. Kebanggan karyawan dalam organisasi }\end{array}$ \\
\hline
\end{tabular}

Sumber : Berbagai referensi data, diolah sendiri, 2020 


\section{ENTREPRENEUR}

Jurnal Bisnis Manajemen Dan Kewirausahaan

Program Studi Manajemen Fakultas Ekonomika dan Bisnis Universitas Majalengka Published every January and July e-ISSN : (Proses), p-ISSN: 2723-1941

Available online https://ejournal.unma.ac.id/index.php/entrepreneur

HASIL DAN PEMBAHASAN

\section{Hasil}

\section{Pengujian Instrumen Penelitian}

Pengujian ini dilakukan untuk mengetahui sejauh mana alat ukur yang digunakan mampu mengukur apa yang peneliti ukur (Sugiyono, 2013). Berikut kriteria pengujiannya :
1. Apabila nilai $r$ hitung $>$ nilai $r$ tabel berarti dinyatakan valid

2. Apabila nilai $r$ hitung < nilai $r$ tabel berarti dinyatkan tidak valid

Berdasarkan atas pengolahan data yang dilakukan dengan menggunakan program SPSS sebagai berikut:

Tabel 2. Hasil Uji Validitas

\begin{tabular}{cccc}
\hline \multicolumn{2}{c}{ Work Family } & Conflict & \multicolumn{2}{c}{ Komitmen Organisasi } \\
\hline Nomor & R Hitung & Nomor & R Hitung \\
\hline 1 & 0.311 & 1 & 0.421 \\
2 & 0.359 & 2 & 0.543 \\
3 & 0.287 & 3 & 0.500 \\
4 & 0.338 & 4 & 0.433 \\
5 & 0.321 & 5 & 0.621 \\
6 & 0.478 & 6 & 0.351 \\
7 & 0.459 & & \\
8 & 0.464 & & \\
\hline
\end{tabular}

Sumber : Hasil output program SPSS 21 yang diolah pada tahun 2020

Hasil perhitungan uji validitas di atas menunjukan bahwa setiap pernyataan pada variabel Work Family Conflict dan komitmen organisasi dinyatakan valid. Dikarenakan nilai $r_{\text {hitung }}$ untuk setiap pernyataan lebih besar dari $r_{\text {tabel }}$ dengan signifikansi 5\% yakni sebesar 0,195.

Uji realibilitas merupakan ukuran dari satu kestabilan dan konsistensi dari responden dalam menjawab pernyataan yang merupakan dimensi atau indikator suatu variabel dan telah disusun ke dalam bentuk kuesioner. Suatu instrumen dinyatakan reliabel atau handal jika memiliki nilai cornbach's alpha lebih besar dari 0,60 (Sugiyono, 2013). Hasil pengujiannya dapat dilihat pada tabel sebagai berikut :

Tabel 3. Hasil Uji Reliabilitas

\begin{tabular}{|c|c|c|c|c|}
\hline Variabel & $\begin{array}{c}\text { Total Item } \\
\text { Pernyataan }\end{array}$ & $\begin{array}{c}\text { Nilai } \\
\text { Cronbach's } \\
\text { Alpha }\end{array}$ & Nilai Kritis & Keterangan \\
\hline $\begin{array}{c}\text { Work Family } \\
\text { Conflict }\end{array}$ & 5 & 0.613 & 0.60 & Reliabel \\
\hline $\begin{array}{c}\text { Komitmen } \\
\text { Organisasi }\end{array}$ & 6 & 0.711 & 0.60 & Reliabel \\
\hline
\end{tabular}

Sumber : Hasil output program SPSS 21 yang diolah pada tahun 2020 


\section{ENTREPRENEUR}

Jurnal Bisnis Manajemen Dan Kewirausahaan

Program Studi Manajemen Fakultas Ekonomika dan Bisnis Universitas Majalengka

Published every January and July e-ISSN : (Proses), p-ISSN: 2723-1941

Available online https://ejournal.unma.ac.id/index.php/entrepreneur

Hasil pengujian Reliabilitas menunjukan bahwa nilai cronbach's alpha pada setiap variabel yang diteliti memiliki nilai cornbach's alpha lebih besar jika dibandingkan dengan nilai kritisnya 0.60 . Maka disimpulkan bahwa setiap pernyataan yang digunakan dalam penelitian ini dinyatakan reliable atau handal.

\begin{tabular}{c}
$\begin{array}{c}\text { Tabel 4. Hasil Uji Hipotesis } \\
\text { Coefficients }\end{array}$ \\
\hline Variabel \\
t
\end{tabular}

\begin{tabular}{lll}
\hline Work & -2.778 & .000 \\
Family & & \\
Conflict & & \\
\hline
\end{tabular}

Sumber : Hasil output program SPSS 21 yang diolah pada tahun 2020

Hasil uji hipotesis diperoleh bahwa ambiguitas peran (X) memiliki nilai $t_{\text {hitung }}$ sebesar -2,778 dengan $t_{\text {tabel }}$ sebesar 1,984 dengan signifikasi 5\% maka $t_{\text {hitung }}(-2.778)$ $>t_{\text {tabel }}(1,984)$ dan nilai signifikasinya 0,06

\section{Pengaruh Work Family Conflict Terhadap Komitmen Organisasi}

Work Family Conflict memiliki pengaruh yang negatif dan signifikan terhadap komitmen organisasi. Tinggi rendahnya work family conflict yang dirasakan oleh seorang karyawan tentunya akan mempengaruhi dari komitmen organisasinya. Apabila work family conflict semakin tinggi maka komitmen organisasinya akan semakin rendah begitupun sebaliknya. Work Family Conflict yang dialami oleh karyawan PT. Shoetown Kabupaten Majalengka dikategorikan tinggi. Kondisi seperti ini nampak pada saat mereka menyelesaikan pekerjaan yang dilakukan dengan cara yang berbeda, mereka juga rentan mengesampingkan aturan dalam menyelesaikan pekerjaan dan sering kali menerima permintaan dari kedua pihak
$<0,05$ maka Ha dapat diterima. Hasil ini menunjukan bahwa Work Family Conflict berpengaruh signifikan dan arah hubunganya negatif terhadap komitmen organisasi.

atau lebih yang tidak ada kesesuaian antara satu dengan yang lainnya, mereka melakukan pekerjaan yang cenderung diterima satu pihak saja dan seringkali melakukan pekerjaan yang tidak perlu. Semakin mereka berada dalam keadaan tersebut, maka menurunkan kesetiaan mereka akan berkurang dan hilangnya kebanggan terhadap perusahaan tempatnya bekerja.

Penelitian ini didukung oleh penelitian (Legowo et al., 2019) dengan judul Pengaruh Work Family Conflict Dan Stres Kerja Terhadap Komitmen Organisasi Dengan Kepuasan Kerja Sebagai Variabel Intervening Pada Dinas Pekerjaan Umum Dan Penataan Ruang Kabupaten Sukoharjo, yang menyatakan bahwa Work Family Conflict memiliki pengaruh yang negative signifikan terhadap komitmen organisasi. Artinya bahwa semakin tinggi work family 


\section{ENTREPRENEUR}

Jurnal Bisnis Manajemen Dan Kewirausahaan

Program Studi Manajemen Fakultas Ekonomika dan Bisnis Universitas Majalengka

Published every January and July e-ISSN : (Proses), p-ISSN: 2723-1941

Available online https://ejournal.unma.ac.id/index.php/entrepreneur

conflict yang dialami oleh pegawai, maka akan semakin rendah komitmen organisasi dalam diri seorang gawai.Selanjutnya penelitian ini mendukung juga penelitian yang dilakukan oleh (Saraswati et al., 2014) dengan penelitian mengenai Pengaruh Tekanan Klien, Konflik Peran dan Ambiguitas Peran Terhadap Komitmen Independensi Aparat Inspektorat Pemerintah Daerah ( Studi Empiris Pada Inspektorat Kota Denpasar dan Kabupaten Gianyar) yang berpendapat bahwa setiap individu yang mengalami konflik peran akan dengan mudah mengalami rasa cemas, rasa ketidakpuasan dan merasa adanya ketidakefektifan untuk bekerja jika dibandingkan individu yang lainnya.

\section{SIMPULAN DAN IMPLIKASI Simpulan}

Work Family conflict berpengaruh negative dan signifikan terhadap komitmen organisasi. Hal ini berarti tinggi rendahnya work family conflict akan memengaruhi tinggi rendahnya komitmen dalam organisasi. Dapat dilihat dari cara karyawan P\}T. Shoetown Kabupaten Majalengka yang masih mengesampingkan aturan dalam menyelesaikan pekerjaan dalam hal ini pekerjaan yang tidak memiliki kesesuaian antara satu dengan lainnya. Sehingga komitmen organisasinya masih rendah.

\section{Saran}

Implikasi manajerial dalam penelitian ini terutama berkaitan dengan komitmen organisasi karyawan PT. Shoetown Kabupaten Majalengka, sebaiknya perusahaan lebih memerhatikan karyawan yang berperan sebagai istri, ibu dan juga seorang pekerja dimana mereka tidak bisa mendeskrifsikan dengan jelas tugas mana yang perlu didahulukan, mengingat tanggungjawab mereka besar di perusahaan maupun dirumah.

\section{DAFTAR PUSTAKA}

Amelia, A. (2010). Pengaruh Work-ToFamily Conflict dan Family-ToWork Conflict Terhadap Kepuasan dalam Bekerja, Keinginan Pindah Tempat Kerja, dan Kinerja Karyawan. In Jurnal Ekonomi dan Bisnis (Vol. 4, Issue 3).

Anisykurlillah $\square$, I., Wahyudin, A., \& Kustiani. (2013). PENGARUH ROLE STRESSOR TERHADAP KOMITMEN ORGANISASI DENGAN KEPUASAN KERJA SEBAGAI VARIABEL INTERVENING PADA KANTOR AKUNTAN PUBLIK (KAP) DI JAWA TENGAH. Jurnal Dinamika Akuntansi, 5(2), 109-120.

Legowo, Wahyudi, A., \& Suprayitno. (2019). PENGARUH WORK FAMILY CONFLICT DAN STRES KERJA TERHADAP KOMITMEN ORGANISASI DENGAN KEPUASAN KERJA SEBAGAI VARIABEL INTERVENING PADA DINAS PEKERJAAN UMUM DAN PENATAAN RUANG KABUPATEN SUKOHARJO. Jurnal Manajemen 


\section{ENTREPRENEUR \\ Jurnal Bisnis Manajemen Dan Kewirausahaan}

Program Studi Manajemen Fakultas Ekonomika dan Bisnis Universitas Majalengka Published every January and July e-ISSN : (Proses), p-ISSN: 2723-1941 Available online https://ejournal.unma.ac.id/index.php/entrepreneur

Sumber Daya Manusia, 13(2), 287 299.

Robbin, S. P., \& Judge, T. A. (2015).

Perilaku Organisasi (Enam Belas).

Salemba Empat.

Saraswati, N. P. I. P., Atmadja, A. T., \& Darmawan, N. A. S. (2014). Pengaruh Tekanan Klien, Konflik Peran dan Role Ambiguity Terhadap Komitment Independensi Aparat Inspektorat Pemerintah Daerah (Studi Empiris Pada Inspektorat Kota Denpasar dan Kabupaten Gianyar). E-Journal S1 Ak Universitas Pendidikan Ganesha Jurusan Akuntansi Program S1, 2(1).

https://doi.org/http://dx.doi.org/10.2 3887/jimat.v2i1.2977

Sugiyono. (2013). Metode Penelitian Pendidikan Pendekatan Kuantitaif, Kualitatif, dan R\&DSugiyono. 2013. "Metode Penelitian Pendidikan Pendekatan Kuantitaif, Kualitatif, dan R\&D." Metode Penelitian Pendidikan Pendekatan Kuantitaif, Kualitatif, dan R\&D. https://doi.org/10.1. In Metode Penelitian Pendidikan Pendekatan Kuantitaif, Kualitatif, dan $R \& D$. https://doi.org/10.1007/s13398-0140173-7.2 